\title{
Pengaruh Pemberian Air Minum Dan Herbal Berbasis Magnetic Water Treatment Terhadap Performa Ayam Pedaging
}

\author{
Miarsono Sigit ${ }^{1}$, Ainun Nikmah ${ }^{2}$ \\ ${ }^{1}$ Fakultas Kedokteran Hewan, Universitas Wijaya Kusuma Surabaya \\ Jl. Dukuh Kupang XXV-54 Surabaya \\ ${ }^{2}$ Program Studi Peternakan Fakultas Pertanian Universitas Islam Kadiri Kediri \\ Jalan Sersan Suharmadji No. 38 Manisrenggo, Kec. Kota Kediri \\ Corresponding author : miarsono sigit@uwks.ac.id
}

\begin{abstract}
Abstrak
Penelitian ini bertujuan untuk mengetahui pengaruh pemberian air minum dan herbal berbasis magnetic water treatment terhadap performa ayam pedaging. Penelitian ini dilaksanakan dengan menggunakan metode eksperimental dengan menggunakan Rancangan Acak Lengkap dengan 5 perlakuan dan 5 ulangan. Perlakuan terdiri atas : Perlakuan Kontrol (P0); Air magnetisasi selama 30 menit tanpa pemberian herbal (P1); Air + herbal sebanyak $1,5 \mathrm{ml} / \mathrm{l}$ air minum kemudian di magnetisasi selama 30 menit (P2); Air + herbal sebanyak 2,5 ml/l air minum kemudian di magnetisasi selama 30 menit (P3); Air + herbal sebanyak $3,5 \mathrm{ml} / \mathrm{l}$ air minum kemudian di magnetisasi selama 30 menit (P4). Data yang didapatkan kemudian dianalisis menggunakan sidik ragam (ANOVA). Hasil dari penelitian ini menunjukkan bahwa P0, P1, P2, dan P3 tidak memberikan pengaruh terhadap konsumsi pakan, konsumsi air minum, pertambahan bobot badan, konversi pakan dan mortalitas. Pemberian air minum dan herbal dosis $3,5 \mathrm{ml} /$ iter air minum (P4) memberikan pengaruh terhadap pertambahan bobot badan. Kesimpulan dari penelitian ini bahwa herbal magnetisasi dapat diberikan dengan dosis $3,5 \mathrm{ml} /$ liter air minum.
\end{abstract}

Kata Kunci : magnetic water treatment, herbal, air minum, performa ayam pedaging.

\begin{abstract}
The aimed of this study to determined the effect of maximum water and herbal magnetic water reatment based on the performance of broilers. This research was carried out using an experimental method by refining the Complete Randomized Design with 5 treatments and 5 replications. Treatment listed above: Treatment Control (PO); Water magnetization for 30 minutes without giving herbal (PI), Water + herbal as much as $1.5 \mathrm{ml} /$ liter of drinking water then magnetized for 30 minutes (P2), Water + herbal as much as $2.5 \mathrm{ml} /$ liter of drinking water then magnetized for 30 minutes (P3); Herbal water as much as $3.5 \mathrm{mll} /$ liter of drinking water is then magnetized for 30 minutes (P4). The data analyzed by shown (ANOVA). The results of this study indicate that the PO, P1, P2, and P3 do not provide care for feed consumption, drinking water consumption, body weight gain, feed conversion and mortality. Provision of drinking water and herbal doses of $3.5 \mathrm{ml}$ liters of drinking water (P4) have an influence on weight gain. The conclude of this study is that P4 gives a higher increase in body weight compared to other treatments.
\end{abstract}

\section{Keywords : magnetic water treatment, herbal, drinking water, performance of broilers.}

\section{Pendahuluan}

Dewasa ini peternakan unggas khususnya peternakan ayam pedaging merupakan salah satu sektor yang mempunyai peranan sangat penting dalam perekonomian nasional untuk memenuhi kebutuhan protein hewani masyarakat. Hal ini dikarenakan meningkatnya permintaan daging ayam seiring dengan meningkatnya kesadaran penduduk akan pentingnya protein hewani (Ahmad dan Elfawati, 2008). Usaha peternakan ayam pedaging di Indonesia dapat dijumpai hampir di setiap provinsi.
Usaha peternakan ayam dipengaruhi oleh tiga faktor utama yaitu penyediaan bibit unggul, pemenuhan kebutuhan pakan, dan manajemen pemeliharaan yang baik. Ketiga faktor tersebut berperan sangat penting dalam menentukan keberhasilan suatu usaha peternakan ayam. Untuk mencapai efisiensi produktivitas usaha diperlukan pengkoordinasian yang baik antara pemilihan bibit, pemenuhan kebutuhan pakan, dan program manajemen pemeliharaan. Salah satu langkah yang dapat dilakukan untuk meningkatkan efisiensi penggunaan pakan adalah dengan menambahkan feed additive. 
Feed additive adalah bahan yang tidak termasuk zat makanan yang ditambahkan dengan jumlah sedikit dan bertujuan untuk memacu pertumbuhan dan meningkatkan populasi mikroba yang menguntungkan yang ada di dalam saluran pencernaan ayam. Penggunaan feed additive komersial selain harganya tinggi juga kurang terjamin aspek keamananya karena adanya residu bahan kimia dalam daging ayam. Salah satu cara untuk mengantisipasi hal tersebut adalah dengan memanfaatkan tanaman berupa Jamu tradisional atau herbal.

Herbal merupakan obat tradisional yang terbuat dari bahan alami tumbuhtumbuhan telah digunakan secara turun temurun untuk menjaga stamina dan mengobati beberapa jenis penyakit. Herbal adalah feed aditive yang dipercaya oleh peternak Indonesia yang berkhasiat dalam upaya meningkatkan produktivitas ternak. Penggunaan herbal sebagai feed additive dalam ransum broiler bertujuan untuk mengganti penggunaan antibiotik sebagai growth promotor dan pencegah penyakit pada ternak unggas sehingga ternak dan manusia dapat terhindar dari residu antibiotik dan resistensi bakteri.

Air memiliki peranan yang sangat penting dalam kehidupan makhluk hidup termasuk pada ternak. Ayam dapat bertahan hidup hingga 3 minggu tanpa pakan, namun ayam tidak akan dapat bertahan hidup meskipun hanya beberapa hari tanpa air minum. Air dibutuhkan untuk mencerna makanan dan membantu penyerapan nutrisi agar lebih optimal. Dalam bidang peternakan banyak inovasi yang diterapkan untuk meningkatkan performa ayam pedaging, salah satunya yaitu pemberian air minum yang diberi magnet (Magnetic Water Treatment).

Air yang di proses dengan medan magnet dapat menurunkan tingkat mortalitas dan morbiditas pada ayam pedaging, selain itu air yang di proses dengan medan magnet juga dapat mempercepat pertambahan bobot badan dalam waktu yang relatif lebih singkat (Gholizadeh et al., 2008). Berdasarkan hal tersebut maka saya selaku penulis ingin mengetahui bagaimana pengaruh pemberian air minum dan herbal berbasis magnetic water treatment dengan dosis berbeda terhadap performa ayam pedaging.

\section{Metodologi Penelitian}

Penelitian ini dilaksanakan di Kandang Lapang Pita Farm Kandangan milik PT. Intertama Trikencana Bersinar Kediri yang bertempat di Desa Klampisan, Kecamatan
Kandangan, Kabupaten Kediri pada 25 Oktober 2019 sampai dengan 23 November 2019. Materi yang digunakan yaitu Ayam pedaging strain Ross (umur 1 hari -30 hari) dengan jenis kelamin campuran (unsexing) sebanyak 125 ekor, pakan, air sumur, herbal tradisional. Penelitian ini dilaksanakan dengan menggunakan metode eksperimental menggunakan Rancangan Acak Lengkap dengan 5 perlakuan dan 5 ulangan. Perlakuan terdiri atas :

P0: Perlakuan Kontrol.

P1: Air magnetisasi selama 30 menit tanpa pemberian herbal.

P2: Air + herbal sebanyak $1,5 \mathrm{ml} / \mathrm{l}$ air minum kemudian di magnetisasi selama 30 menit.

P3: Air + herbal sebanyak $2,5 \mathrm{ml} / \mathrm{l}$ air minum kemudian di magnetisasi selama 30 menit.

P4: Air + herbal sebanyak $3,5 \mathrm{ml} / \mathrm{l}$ air minum kemudian di magnetisasi selama 30 menit.

Setiap unit perlakuan terdiri atas 5 ekor ayam. Hasil data yang didapatkan kemudian dianalisis menggunakan sidik ragam yang sebelumnya telah dilakukan uji asumsi.

\begin{tabular}{|l|l|}
\hline $\begin{array}{l}\text { Bahan dicuci } \\
\text { sampai bersih diiris } \\
\text { tipis kemudian } \\
\text { dihaluskan. }\end{array}$ & $\rightarrow \begin{array}{l}\text { Tambahkan air } \\
\text { kemudian } \\
\text { rebus sampai } \\
\text { mendidih. }\end{array}$ \\
& $\begin{array}{l}\text { Setelah mendidih, } \\
\text { diamkan sejenak } \\
\text { kemudian di saring. }\end{array}$ \\
& $\begin{array}{l}\text { Simpan dalam } \\
\text { keadaan } \\
\text { anaerob. }\end{array}$ \\
\hline
\end{tabular}

Gambar 1. Bagan pembuatan herbal

Variabel yang diamati yaitu : konsumsi pakan, konsumsi air minum, pertambahan bobot badan, konversi pakan dan mortalitas. Komposisi pakan terdiri dari jagung, bungkil kedelai, bekatul, tepung daging dan tulang dan tepung batu dengan kandungan protein kasar minimal $20 \%$, lemak kasar minimal $5 \%$, serat kasar maksimal 5\%, kadar air maksimal 14\%, 
Abu maksimal $8 \%$, Ca sebanyak $0,8-1,10 \%$ dan $\mathrm{P}$ minimal $0,50 \%$.

Bahan herbal yang digunakan terdiri dari: gula jawa, asam jawa, jahe, kunyit, sirih, temulawak, jintan hitam, sambiloto, mengkudu, bawang putih, temu ireng, lempuyang, daun papaya, kencur. Pembuatan ramuan herbal sesuai dengan (gambar 1).

\section{Hasil Dan Pembahasan}

Berdasarkan hasil penelitian diperoleh rata-rata konsumsi pakan, konsumsi air minum, pertambahan bobot badan, mortalitas dan konversi pakan ayam pedaging umur 30 hari dengan pemberian air minum dan herbal berbasis magnetic water treatment dengan dosis berbeda terhadap performa ayam pedaging dapat dilihat pada Tabel 1

Tabel 1. Rata-rata konsumsi pakan, konsumsi air minum, pertambahan bobot badan, mortalitas dan konversi pakan ayam pedaging umur 30 hari.

\begin{tabular}{|c|c|c|c|c|c|}
\hline \multirow{2}{*}{$\begin{array}{c}\text { Variabel } \\
\text { pengamatan }\end{array}$} & \multicolumn{5}{|c|}{ Perlakuan } \\
\hline & P0 & P1 & P2 & P3 & P4 \\
\hline $\begin{array}{l}\text { Konsumsi Pakan } \\
\text { (g/ekor/hari) }\end{array}$ & $86,00 \pm 2,39$ & $85,63 \pm 3,06$ & $84,68 \pm 3,77$ & $83,76 \pm 2,87$ & $86,60 \pm 2,71$ \\
\hline $\begin{array}{l}\text { Konsumsi Air Minum } \\
\text { (mL/ekor/hari) }\end{array}$ & $199,75 \pm 7,06$ & $203,19 \pm 4,71$ & $198,04 \pm 2,83$ & $196,25 \pm 6,78$ & $202,02 \pm 4,93$ \\
\hline $\begin{array}{l}\text { Pertambahan Bobot } \\
\text { Badan } \\
\text { (g/ekor/hari) }\end{array}$ & $56,09 \pm 2,41^{a}$ & $57,44 \pm 1,59^{\mathrm{a}}$ & $57,73 \pm 2,88^{a}$ & $57,21 \pm 3,04^{\mathrm{a}}$ & $61,95 \pm 2,60^{b}$ \\
\hline Konversi Pakan & $1,50 \pm 0,10$ & $1,46 \pm 0,08$ & $1,43 \pm 0,06$ & $1,44 \pm 0,09$ & $1,37 \pm 0,02$ \\
\hline Mortalitas (\%) & $0 \pm 0$ & $0 \pm 0$ & $0 \pm 0$ & $0,80 \pm 0$ & $0 \pm 0$ \\
\hline
\end{tabular}

\section{Konsumsi Pakan}

Konsumsi pakan adalah merupakan faktor yang sangat penting dalam proses penggemukan ternak termasuk ayam pedaging. Semakin banyak pakan yang dikonsumsi maka semakin tinggi pula bobot badan yang dihasilkan, namun banyaknya konsumsi pakan juga mempengaruhi efisiensi pakan. Semakin tinggi bobot badan yang dihasilkan dengan konsumsi pakan yang sedikit maka semakin efisien pemberian pakannya. Hal ini sesuai dengan pendapat Rasyaf (2004) bahwa besarnya pakan yang digunakan memengaruhi perhitungan konversi pakan.

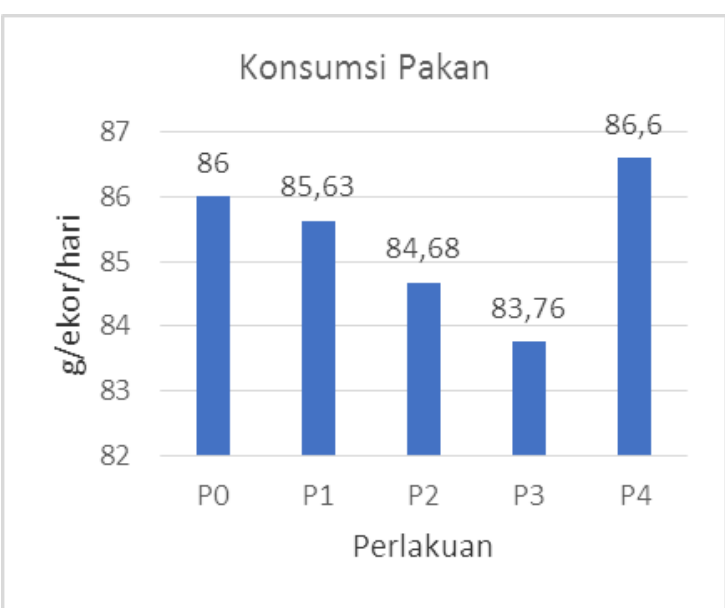

\section{Gambar 2. Grafik Konsumsi Pakan}

Berdasarkan hasil penelitian dan analisis statistik dengan menggunakan ANOVA membuktikan bahwa pemberian air minum herbal berbasis magnetic water treatment tidak menunjukkan pengaruh nyata terhadap konsumsi pakan ayam pedaging umur 30 hari. Meskipun secara perhitungan uji lanjut atau ANOVA hasil menunjukkan tidak berbeda nyata, namun secara data statistik konsumsi pakan tertinggi ada pada P4 dengan rata-rata jumlah konsumsi pakan sebesar 86,60 gram/ekor/hari. Tingginya konsumsi pakan pada P4 ini dipengaruhi oleh komposisi bahan herbal yang diberikan. Komposisi herbal yang diberikan terdapat kunyit, temulawak dan herbal lainnya yang mampu meningkatkan konsumsi pakan pada ayam pedaging karena mengandung senyawa kimia curcumin.

$\mathrm{Hal}$ ini sesuai dengan pernyataan Moelyono (2007) bahwa temulawak dapat digunakan sebagai obat untuk mengatasi penyakit tertentu atau digunakan sebagai penguat daya tahan tubuh. Rimpang temu ireng juga merupakan salah satu obat tradisional yang telah terbukti dapat digunakan untuk menambah nafsu makan, membunuh cacing asakris, dan memacu pertumbuhan.

\section{Konsumsi Air Minum}


Konsumsi air minum merupakan hal yang sangat dibutuhkan oleh tubuh ternak. Karena, sebagian besar komposisi dari tubuh ternak ditopang oleh air. Air mengisi tubuh ternak hingga $60-70 \%$. Hal ini sesuai dengan pendapat Bishop (2011) bahwa ayam mengkonsumsi air minum sekitar 1,6-2 kali dari konsumsi pakan. Tillman dkk., (2008) menambahkan bahwa air merupakan unsur terpenting sebagai pemindah panas yang berfungsi membantu proses pencernaan dan menjadi media untuk transportasi produk metabolisme serta produk sisa metabolisme.

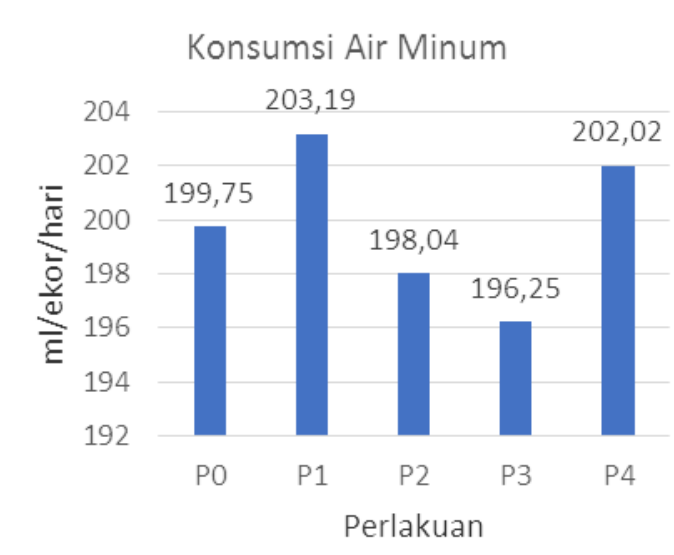

Gambar 3. Grafik Konsumsi Air Minum

Berdasarkan hasil penelitian dan analisis statistik dengan menggunakan ANOVA membuktikan bahwa pemberian air minum herbal berbasis magnetic water treatment tidak menunjukkan pengaruh nyata terhadap konsumsi air minum ayam pedaging umur 30 hari. Meskipun secara statistik tidak berbeda nyata, namun konsumsi air minum tertinggi ada pada P1 sebanyak 231,309 $\mathrm{ml} /$ ekor/hari sedangkan konsumsi air minum terendah ada pada P2 sebanyak 226,891 $\mathrm{ml} /$ ekor/hari. Rata-rata konsumsi air minum setiap harinya semakin bertambah. Konsumsi air minum pada ayam pedaging penelitian mencapai 2300-2500 ml/ekor. Konsumsi air minum antar perlakuan tidak berbeda jauh sehingga hasil analisis data tidak menunjukkan pengaruh yang nyata.

PO konsumsi air rendah karena air minumnya hanya air sumur yang di sterilkan sedangkan air minum perlakuan lainnya telah dimagnetisasi yang dapat menambah palatabilitas sehingga meningkatkan konsumsi air minum. Air minum perlakuan dapat menambah palatabilitas minum pada ayam karena pada air minum tercium aroma yang manis dari herbal, sehingga meningkatkan konsumsi air minum. Setelah Uji Organoleptik dengan indra manusia bahwa herbal yang diberikan memiliki aroma yang menyenangkan namun memiliki rasa yang pahit, akan tetapi setelah herbal dicampur air dengan magnetisasi rasa pahit akan berkurang. Berkurangnya rasa pahit ini kemungkinan diakibatkan oleh magnetisasi serta penambahan air dengan kadar yang sesuai.

Konsumsi air minum yang sering naik turun disebabkan oleh banyak faktor, baik faktor internal dari ayam itu sendiri maupun faktor lingkungan ayam yang memengaruhi kondisi ayam. Konsumsi air minum dapat dipengaruhi oleh Suhu di dalam kandang, strain ayam, konsumsi ransum dan lain lain. Hal ini sesuai dengan pendapat Rasyaf (2004) yang menyatakan bahwa konsumsi air minum dipengaruhi oleh konsumsi ransum, jenis ayam, aktivitas ayam, dan lingkungan.

\section{Pertambahan Bobot Badan}

Bobot badan akhir ternak merupakan merupakan kriteria yang sangat krusial karena digunakan untuk parameter keberhasilan beternak, karena akan menentukan harga jual ternak. Secara umum, semakin tinggi bobot badan yang dihasilkan maka semakin tinggi pula harga pasar yang ditawarkan.

Hasil perhitungan uji lanjut BNT dapat disimpulkan bahwa pemberian air minum herbal berbasis magnetic water treatment memberikan pengaruh nyata meningkatkan bobot badan dibandingkan dengan perlakuan P0, P1, P2 dan P3.

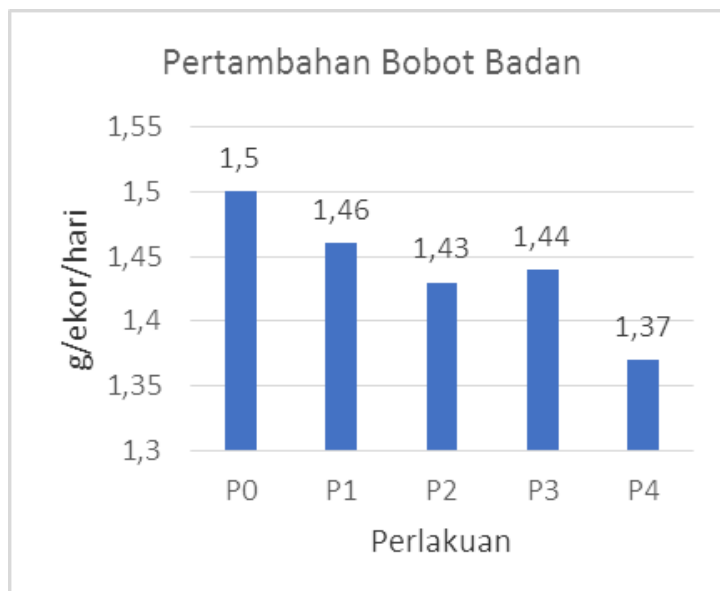

Gambar 4. Grafik Pertambahan Bobot Badan

Rata-rata pertambahan bobot badan pada ayam hasil penelitian mencapai $56-61$ gram/ekor/hari. Rata-rata pertambahan bobot badan tidak berbeda jauh kecuali pada P4. Perlakuan P4 merupakan perlakuan dengan pertambahan bobot badan paling tinggi dibandingkan dengan perlakuan yang lain karena dosis herbal magnetisasi yang diberikan adalah dosis terbesar. Menurut data 
hasil pengujian lanjut dengan menggunakan BNT perlakuan P4 nyata meningkatkan pertambahan bobot badan pada ayam dibandingkan dengan perlakuan kontrol, akan tetapi pemberian herbal magnetisasi sebanyak $1,5 \mathrm{ml} /$ liter dan sebanyak $2,5 \mathrm{ml} /$ iter air minum tidak berpengaruh nyata terhadap pertambahan bobot badan.

Pertambahan bobot badan pada ayam pedaging hasil penelitian dapat dilihat pada Gambar 4. Secara umum pertambahan bobot badan meningkat seiring dengan meningkatnya konsumsi pakan. Peningkatan ini terjadi pada semua perlakuan baik perlakuan kontrol maupun perlakuan herbal magnetisasi, kemudian pertambahan bobot badan mulai menurun apabila ayam sudah mulai tua.

\section{Konversi Pakan}

Konversi pakan adalah nilai yang digunakan untuk mengukur efisiensi penggunaan pakan pada peternakan ayam pedaging. Nilai konversi pakan dikatakan baik apabila kurang dari 2, semakin kecil nilai konversi pakan maka semakin efisien pula konversi pakan menjadi dagingnya. Hal ini sesuai dengan pendapat Amrullah (2003) bahwa nilai konversi pakan dikatakan baik jika dibawah angka 2, berarti bahwa jika mortalitas normal sekelompok ayam pedaging hanya memerlukan pakan kurang dari $2 \mathrm{~kg}$ untuk menghasilkan $1 \mathrm{~kg}$ berat hidup.

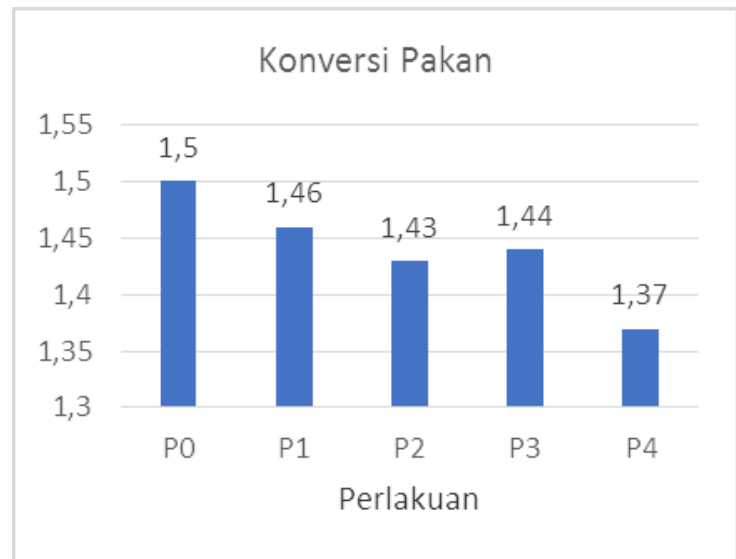

Gambar 5. Grafik Konversi Pakan

Nilai konversi pakan selama penelitian berkisar antara 1,37 - 1,50. Meskipun secara hasil analisis data tidak menunjukkan hasil yang berbeda nyata namun konversi pakan dengan penambahan herbal magnetisasi hingga taraf $3,5 \mathrm{ml} /$ liter air minum (P4) menghasilkan nilai konversi pakan yang lebih rendah yaitu 1,37. Rendahnya angka konversi pakan yang dihasilkan menunjukkan bahwa jumlah pakan yang dibutuhkan untuk meningkatkan bobot badan per satuan berat adalah sedikit, yang berarti bahwa efisiensi penggunaan pakannya tinggi.

Herbal yang diberikan mengandung komposisi bahan yang cukup lengkap sehingga dapat menurunkan konversi pakan menjadi lebih baik. Senyawa curcumin pada bahan herbal mampu meningkatkan nafsu makan, diimbangi dengan kandunga minyak atsiri pada jahe yang mampu menghangatkan tubuh serta membantu pemecahan lemak pada tubuh ayam sehingga bobot badan yang dihasilkan optimal dengan hasil konversi pakan yang baik.

Nilai Konsumsi Pakan sangat memengaruhi Nilai konversi pakan yang dihasilkan. Hal ini sesuai dengan pernyataan Rasyaf (2004) bahwa pertambahan bobot badan haruslah pula dikaitkan dengan konsumsi pakannya karena memengaruhi konversi pakan yang dihasilkan. Banyak faktor yang dapat memengaruhi konsumsi pakan, seperti suhu lingkungan dan lain lain. Rasyaf (2004) menambahkan bahwa nilai konversi pakan dipengaruhi oleh berat tubuh dan bangsa ayam, tahap produksi, dan temperatur lingkungan.

\section{Mortalitas}

Mortalitas atau tingkat kematian pada ayam tentu saja menjadi masalah yang dihindari oleh para peternak. Tingkat mortalitas pada ayam bisa dikatakan normal apabila dibawah 5\%. Angka mortalitas diperoleh dari perbandingan jumlah ayam yang mati dengan jumlah ayam yang dipelihara. Tingkat kematian atau mortalitas dipengaruhi oleh beberapa fakor, antara lain bobot badan, bangsa, jenis ayam, iklim, kebersihan lingkungan, sanitasi peralatan dan kandang serta juga penyakit pada ternak.

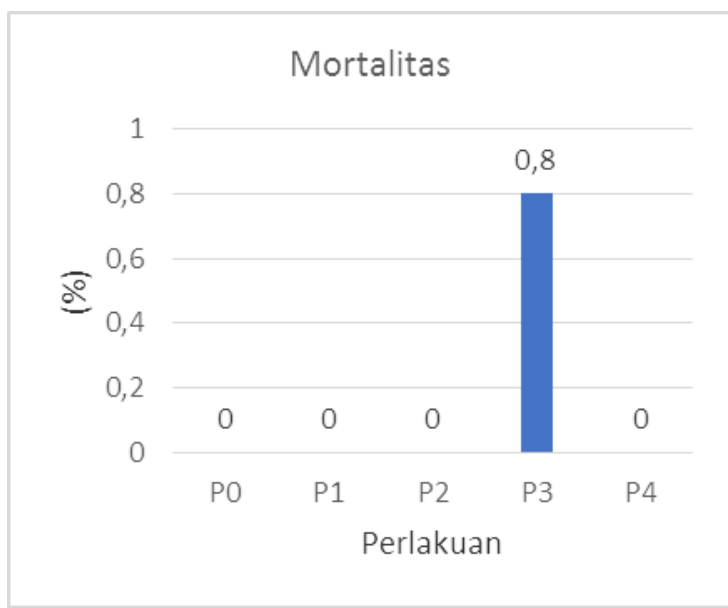

Gambar 6. Grafik Mortalitas 
Kematian ayam terjadi pada hari ke 10 pada perlakuan P3 ulangan ke 2. Kematian ini dimungkinkan terjadi karena ayam bertumpuk. Letak ayam yang jauh dari pemanas membuat ayam kedinginan dan bertumpuk tumpuk untuk menghangatkan diri. Namun, ayam yang berada paling bawah atau yang terjepit akan sulit untuk bernapas dan berakibat pada kematian. Total kematian pada penelitian ini yaitu sebanyak 1 ekor $(0,8 \%)$ dari total populasi sebanyak 125 ekor. Ayam perlakuan dengan mortalitas rendah menunjukkan bahwa perlakuan yang diberikan cukup baik, terbukti dengan tingkat mortalitas yang rendah. Rendahnya kematian kemungkinan ada pengaruh besar dengan pemberian herbal. Herbal yang diberikan mengandung Jintan Hitam yang salah satu fungsinya adalah meningkatkan sistem imun pada ayam. Ayam perlakuan sama sekali tidak diberi obat, hanya vaksin pada umur 13 hari dan pemberian herbal magnetisasi selama periode pemeliharaan.

\section{Kesimpulan Dan Saran}

\section{Kesimpulan}

Pemberian herbal magnetisasi dengan dosis $1,5 \mathrm{ml} / \mathrm{l}$ air minum dan 2,5 ml/l air minum tidak berpengaruh terhadap konsumsi pakan, konsumsi air minum, pertambahan bobot badan, konversi pakan dan mortalitas sama seperti perlakuan kontrol negatif dan kontrol positif. Namun, pemberian air minum dan herbal berbasis magnetic water treatment dengan dosis $3,5 \mathrm{~mL} /$ liter air minum memberikan pengaruh terhadap pertambahan bobot badan dengan hasil pertambahan bobot badan yang lebih tinggi dibanding perlakuan yang lain.

\section{Saran}

Diperlukan penelitian lebih lanjut menggunakan ramuan herbal yang sama dengan kosentrasi yang lebih dari $3,5 \mathrm{~mL} /$ liter air minum untuk mengetahui hasil yang lebih signifikan dalam peningkatan performa ayam pedaging

Diperlukan penelitian lebih mendalam mengenai kemampuan hambat ramuan herbal terhadap jenis mikroba penyebab penyakit pada unggas terutama dalam menanggulangi penyebaran penyakit snot.

\section{Daftar Pustaka}

Ahmad dan Elfawati. 2008. Performans Ayam Broiler yang Diberi Sari Buah Mengkudu (Morinda Citrifolia). Jurnal Peternakan, Vol. 5 (1) Februari 2008 (10-13). Fakultas Pertanian dan Peternakan
Universitas Negeri Sultan Syarif Kasim. Pekanbaru-Riau.

Amrullah, I. K. 2003. Nutrisi Ayam Broiler. Lembaga Satu Gunung Budi: Bogor.

Bishop, 2011. Bagaimana Kualitas Air Minum Farm Broiler Kita.

Http://www.ceva.co.id/Informasi-

Teknis/Informasi-lain/Bagaimana-

Kualitas-Air-Minum-Farm-Broiler-Kita.

Diakses pada tanggal 16 September 2019

Gholizadeh, M., Arabshahi, H., Saeidi, M., \& Mahdavi, B. 2008. The Effect of Magnetic Water on Growth and Quality Improvement of Poultry. Middle-East Journal of Scientific Research,3(3), 140144. doi:1990-9233.

Rasyaf, M. 2004. Beternak Ayam Pedaging. Penebar Swadaya. Jakarta.

Tillman, A. D., Hartadi, H., Reksohadiprodjo, S., Prawirokusumo., S., dan Lebdosoekojo, S. 2008. Ilmu Makanan Ternak Dasar. Cetakan ke 6. Gadjah Mada University. Yogyakarta. 